\title{
Strategi Pendampingan Melalui Bauran Pemasaran Di BMT NU Sejahtera KC Harjamukti Dalam Menghadapi Masa Pandemi
}

\author{
Yati Haryati $^{*}$, Ellina Nopidia ${ }^{2}$, Ellisa Septiani ${ }^{3}$, Fitrohtul Laeli $^{4}$ \\ IAIN Syekh Nurjati Cirebon \\ 1e-mail: yh.yatiharyati@gmail.com \\ 2 e-mail: nopidiaellin@gmail.com \\ ${ }^{3}$ e-mail: ellisaseptiani1 @ gmail.com \\ 4e-mail: flaeli53@gmail.com \\ *Corresponding Author
}

\begin{abstract}
ABSTRAK
Tujuan dari kegiatan pengabdian ini adalah sebagai upaya meningkatkan kualitas manajemen BMT NU Sejahtera Kc Harjamukti dalam menghadapi masa pandemi Covid 19. BMT berdiri pada akhir januari tahun 2019 dan memiliki perkembangan yang cukup bagus. Pandemi covid 19 yang terjadi di dunia, mengakibatkan banyak perubahan terutama pada penurunan ekonomi, dampak tersebut dirasakan pula oleh BMT NU Sejahtera. Alat analisis yang digunakan adalah bauran pemasaran yang terdiri dari $4 \mathrm{P}$, yaitu product, price, place dan promotion. Kegiatan pendampingan ini menggunakan metode deskriptif kualitatif, dengan cara melakukan wawancara langsung pada pihak BMT NU Sejahtera. Hasil pendampingan menemukan bahwa BMT melakukan penyesuaian angsuran agar lebih terjangkau oleh nasabah, menerapkan protokol kesehatan pada lokasi BMT, serta melakukan promosi berupa periklanan. Hal yang dapat dilakukan untuk meningkatkan kualitas bauran pemasaran adalah mengemas produk agar lebih menarik, mengoptimalkan protokol kesehatan di lokasi BMT, melakukan promosi online serta pemasangan nama BMT di lokasi yang strategis.
\end{abstract}

Kata Kunci: BMT, Covid 19, Strategi, Bauran Pemasaran

\begin{abstract}
The aim of this community service activity is as an effort to improve the quality of BMT NU Sejahtera Kc Harjamukti management in the face of the Covid 19 pandemic. BMT was established at the end of January 2019 and has a pretty good development. The Covid 19 pandemic that occurred in the world, resulted in many changes, especially in the economic decline, this impact was also felt by BMT NU Sejahtera. The analytical tool used is the marketing mix which consists of 4P, namely product, price, place and promotion. This study used a qualitative descriptive method, by conducting direct interviews with BMT NU Sejahtera. The results found that BMT made installments adjustments to make it more affordable to customers, implemented health protocols at BMT locations, and carried out promotions in the form of advertising. Things that can be done to improve the quality of the marketing mix are packaging the products to make them more attractive, optimizing health protocols at BMT locations, conducting online promotions and installing BMT names in strategic locations.
\end{abstract}

Keywords: BMT, Covid 19, Strategy, Marketing mix 


\section{PENDAHULUAN}

Lembaga keuangan yang berbasis syariah di Indonesia memiliki perkembangan yang sangat pesat. Salah satunya lembaga keuangan ekonomi berbasis syariah selain bank syariah yaitu BMT (Baitul Maal Wat Tamwil). BMT adalah salah satu jenis lembaga keuangan non bank yang bergerak dalam skala mikro sebagaimana Koperasi Simpan Pinjam (KSP). BMT melakukan penghimpunan dana dari anggota, calon anggota, koperasi lain, dan anggotanya dalam bentuk simpanan serta simpanan berjangka. Tumbuh dan berkembangnya kegiatan BMT tergantung pada kepuasan nasabah, karena apabila nasabah merasa puas maka mereka akan tetap loyal terhadap BMT tersebut (Rachma, 2018) Saat ini perkembangan Koperasi Simpan Pinjam Pembiayaan Syariah (KSPPS) BMT NU Sejahtera cabang Harjamukti, mengalami perkembangan cukup pesat walaupun KSPPS (BMT) NU Sejahtera cabang harjamukti baru berdiri satu setengah tahun tetapi progresnya sudah kelihatan.

Pada bulan Maret 2020 wabah virus Covid-19 telah masuk ke Indonesia yang mengakibatkan terjadi masalah krisis ekonomi yang dampaknya dapat dirasakan oleh semua kalang termasuk KSPPS (BMT) NU Sejahtera cabang Harjamukti. Banyak tantangan yang dihadapi oleh KSSPS (BMT) NU Sejahtera cabang Harjamukti. Pada masa pandemi ini, masyarakat mengalami dampak menurunnya perekonomian, sehingga diperlukan analisis mengenai perubahan kebutuhan pelanggan atau nasabah terhadap BMT NU Sejahtera Kc Harjamukti. Proses penciptaan nilai dalam pemasaran meliputi dua elemen penting, yaitu menciptakan nilai bagi pelanggan (creating value for customers) dan meraih nilai dari pelanggan (capturing value from customers in return). Salah satu langkah yang bisa dilakukan untuk menciptakan nilai bagi pelanggan adalah dengan program bauran pemasaran, yaitu product, price, place dan promotion atau 4P (Tjiptono dan Diana, 2020).

Kegiatan pendampingan terkait strategi KPPS BMT NU masih sedikit, namun kegiatan penelitian mengenai strategi perbankan menggunakan analisis bauran pemasaran, telah banyak dilakukan oleh peneliti sebelumnya. Bauran pemasaran mempengaruhi keputusan pembelian produk oleh nasabah (Astuti \& Sunanto, 2016). Selain itu terdapat penelitian lain yang menjelaskan bahwa faktor bauran pemasaran atau marketing mix, berpengaruh terhadap keputusan nasabah untuk menabung (Andespa, 2017). Analisis marketing mix diperlukan untuk menjaga kepercayaan nasabah serta menarik minat nasabah baru untuk mempergunakan produk yang ada. Berdasarkan pembahasan latar belakang tersebut, penulis tertarik untuk melakukan pembahasan mengenai Strategi Pendampingan Melalui Bauran Pemasaran di KSPPS Baitul Mal Wat Tamwil (BMT) NU Sejahtera Harjamukti dalam Menghadapi Masa Pandemi Covid 19. 


\section{BAHAN DAN METODE}

BMT (Baitul Maal Wat Tamwil) terdiri dari dua istilah, yaitu baitul maal dan baitul tamwil. Baitul maal merupakan usaha-usaha yang mengarah pada pengumpulan dan penyaluran dana yang non profit, seperti: zakat, infaq dan shodaqoh. Sedangkan baitul tamwil sebagai usaha pengumpulan dan penyaluran dana komersial (Ridwan, 2004). Asas dan Landasan BMT berasaskan pancasila dan UUD 45 serta berlandaskan prinsip syariah Islam, keimanan, kekeluargaan, keterpaduan, kemandirian, kebersamaan dan profesionalisme. BMT adalah salah satu jenis lembaga keuangan non bank yang bergerak dalam skala mikro sebagaimana Koperasi Simpan Pinjam (KSP). BMT melakukan penghimpunan dana dari anggota, calon anggota, koperasi lain, dan anggotanya dalam bentuk simpanan serta simpanan berjangka. Tumbuh dan berkembangnya kegiatan BMT tergantung pada kepuasan nasabah, karena apabila nasabah merasa puas maka mereka akan tetap loyal terhadap BMT tersebut (Rachma, 2018)

Bauran pemasaran merupakan serangkaian aktivitas terkendali yang digunakan perusahaan untuk merespon keinginan pasar sasaran. Bauran pemasaran terdiri dari 4P, yaitu product (komponen produk bisa berupa variasi, kualitas, desain, kemasan dan layanan.), price (komponen harga bisa berupa list price, diskon, jangka pembayaran dan syarat kredit), place (komponen tempat bisa berupa saluran distribusi, lokasi, sediaan, transportasi dan logistik), dan promotion (komponen promosi bisa berupa periklanan, personal selling, public relation, direct marketing dan promosi penjualan) (Tjiptono \& Diana, 2020).

\section{Product (Produk)}

Produk merupakan sesuatu yang ditawarkan kepada pasar sasaran baik berupa produk nyata (tangible) maupun produk tidak nyata/jasa (intangible) (Tjiptono \& Diana, 2020; Shinta, 2011). Produk diciptakan untuk memenuhi kepuasan, keinginan dan kebutuhan pasar. Terdapat dua macam kelompok product/goods yaitu:

a. Consumer's Goods, merupakan barang yang yang digunakan langsung oleh konsumen.

b. Industrial Goods, merupakan barang yang dibeli untuk kemudian dijual kembali atau barang yang akan diproses atau akan dilakukan pengohalan lebih lanjut.

\section{Price (Harga)}

Harga merupakan suatu nilai atau sejumlah uang yang harus dibayar konsumen untuk mendapatkan barang dan atau jasa. Faktor yang mempengaruhi penetapan harga adalah tujuan pemasaran, seperti maksimalisasi laba, mempertahankan kelangsungan hidup perusahaan, mengatasi persaingan, tanggung jawab sosial dan lain-lain (Shinta, 2011). 
Dalam penetapan harga, kaum produsen menentukannya dalam dua bentuk:

a. Harga setinggi mungkin (skimming price)

Harga ini dapat dilakukan karena belum ada saingan, produk ini dipasarkan untuk orang kaya. Juga produsen mengharapkan laba yang besar untuk menutup biayabiaya laboratorium untuk menciptakan barang baru tersebut.

b. Produsen juga bisa menetapkan harga serendah mungkin yang disebut dengan penetration price. Tujuan penetapan harga rendah ini adalah untuk meneroboskan produk masuk pasar.

Penetapan harga juga dapat dipengaruhi oleh kebijaksanaan grosir maupun retailer. Dalam kebijaksanaan grosir, grosir atau pedagang besar dapat membuat kebijaksanaan harga dengan memberikan diskon. Diskon tersebut diberlakukan oleh grosir kepada retailer dengan berbentuk potongan pembayaran tunai, membeli dalam jumlah banyak atau melihat jauh dekatnya jarak lokasi pedagang eceran tersebut. Hal ini berarti grosir mempertimbangkan biaya transportasi dalam pengangkutan barang.

Adapun dalam kebijaksanaan retailer, terdapat beberapa macam kebijaksanaan harga yang dilakukan oleh retailer yaitu sebagaimana berikut;

a. Margin pricing

b. Price lining

c. Competitors price

d. Judgement pricing

e. Costumary prices

f. Odd prices; dan

g. Combination offers

3. Place

Place merupakan logistik perusahaan dan aktivitas perusahaan yang berkenaan dengan penyediaan dan pendistribusian produk dana atau jasa akhir kepada konsumen akhir (Tjiptono \& Diana, 2020).

4. Promotion

Promotion merupakan suatu kegiatan pemasaran yang berusaha menyebarkan informasi, mempengaruhi, atau mengingatkan pasar sasaran terhadap suatu perusahaan dan produknya, agar bersedia menerima, membeli dan loyal pada produk yang ditawarkan. Promosi terdiri dari;

a. Personal selling, merupakan presentasi melalui percakapan satu atau dua orang penjual dengan tujuan melakukan penjualan. 
b. Periklanan, merupakan bentuk presentasi atau penyakian dan promosi mengenai ide, barang-barang atau jasa yang dilakukan spnsor tertentu.

c. Publisitas, bertujuan untuk memberikan citra baik dari masyarakat terhadap perusahaan.

d. Promosi penjualan, yaitu promosi dengan cara memberi dorongan kepada pembeli hanya mau membeli suatu produk dengan imbalan akan mendapat hadiah ataupun suatu bonus tertentu.

e. Direct marketing, yaitu promosi yang dilakukan secara kontak langsung dengan pelanggan maupun konsumen potensial. (Alma, 2013).

Metode pendampingan yang dilakukan adalah dengan melalukan pendampingan langsung dengan memberikan saran dan memberikan problem solving berdasarkan dari permasalahan yang muncul pada saat Pandemi. Pendampingan dilakukan selama satu bulan, yaitu pada bulan September 2020. Lokasi pendampingan adalah di Kantor BMT NU sejahtera Kc. Harjamukti yang beralamat di Komplek Pusat Perdagangan Harjamukti Ruko 1A No. 27 Cirebon.

\section{HASIL DAN PEMBAHASAN}

KSPPS (BMT) NU Sejahtera lahir pada tanggal 23 Juli 2003 oleh MWC NU Gunungpati Kota Semarang. Memiliki kantor 1 kantor pusat di Kota Semarang, dan memiliki kantor cabang yang tersebar di Jatim, Jateng dan Jabar (https://ksppsnus.com). Kemudian pada akhir januari tahun 2019 KSPPS (BMT) NU Sejahtera membuka kantor cabang di harjamukti yang beralamat di Komplek pusat perdagangan harjamukti ruko 1a no. 27 Cirebon. BMT NU Sejahtera Kc Harjamukti memiliki nasabah yang cukup banyak dan beragam, mulai dari pedagang di Pusat Perdagangan Harjamukti dan nasabah-nasabah yang berasal dari luar Pusat Perdagangan Harjamukti.

Pandemi covid 19 melanda dunia, hal tersebut memiliki dampak yang begitu besar pada masyarakat. Penyebaran virus ini sangat cepat. Penyebarannya bisa melalui kontak fisik secara langsung antar manusia, yaitu melalui hidung, mulut dan mata. Pemerintah di berbagai negara, termasuk Indonesia, melakukan berbagai upaya pencegahan untuk memutus penularan covid 19. Di Indonesia upaya yang dilakukan salah satunya yaitu Pembatasan Sosial Berskala Besar (PSBB). Dampak covid 19 dirasakan diberbagai sektor kehidupan masyarakat, pembatasan sosial, menurunnya perekonomian, pusat perbelanjaan seperti pasar dan mall yang sepi pengunjung, pendidikan mulai dari tingkat dasar sampai perguruan tinggi dilakukan secara online, kawasan pariwisata dilakukan penutupan sementara, para pedagang mengalami penurunan pendapatan, pelayanan transportasi diperketat (seperti harus dilakukan rapid tes terlebih dahulu sebelum 
melakukan keberangkatan, tempat duduk antar penumpang harus diberi jarak dan, penumpang wajib mengenakan masker).

Pada awal Covid-19 masuk ke indonesia semua kalangan merasakan dampak penurunan ekonomi termasuk KSPPS (BMT) NU Sejahtera Kc Harjamukti. Dampak yang dirasakan adalah adanya pelonjakan tunggakan dari nasabah-nasabah yang melakukan pembiayaan sehingga membuat pemasukan berkurang. Persentase nasabah yang memiliki kendala dalam pembayaran terjadi mulai bulan februari dan meningkat secara tajam di bulan mei dan juni. Jika di analisis, pada bulan februari dan maret, merupakan awal masa pandemi melanda Indonesia, masyarakat diharapkan untuk tetap berada di rumah, untuk memutus rantai penyebaran covid 19, sehingga nasabah merasakan dampak penurunan ekonomi dan berimbas pada kenaikan persentase di bulan mei dan juni.

Selain dampak adanya penambahan jumlah nasabah yang memiliki kendala pembayaran pada masa pandemi. Terdapat pula beberapa produk simpanan yang belum ada penggunanya. Seperti simpanan berjangka dan simpanan khusus. Hal tersebut dimungkinkan karena BMT NU Sejahtera yang baru berdiri kemudian terjadinya pandemi, sehingga belum optimal dalam menyebarkan informasi mengenai produk serta kelebihan-kelebihan yang dimiliki produk tersebut.

Analisis yang digunakan untuk merancang strategi BMT NU Sejahtera Kc. Harjamukti dalam menghadapi permasalahan yang terjadi selama masa pandemi covid 19, yaitu bauran pemasaran atau marketing mix. Bauran pemasaran memiliki pengaruh terhadap loyalitas nasabah, semakin tinggi bauran pemasaran, maka akan semakin tinggi pula loyalitas nasabah (Zuhria \& Anwar, 2018). Bauran pemasaran merupakan serangkaian aktivitas terkendali yang digunakan perusahaan untuk merespon keinginan pasar sasaran. Bauran pemasaran terdiri dari 4P, yaitu product (komponen produk bisa berupa variasi, kualitas, desain, kemasan dan layanan.), price (komponen harga bisa berupa list price, diskon, jangka pembayaran dan syarat kredit), place (komponen tempat bisa berupa saluran distribusi, lokasi, sediaan, transportasi dan logistik), dan promotion (komponen promosi bisa berupa periklanan, personal selling, public relation, direct marketing dan promosi penjualan) (Tjiptono \& Diana, 2020). Berikut ini adalah analisis penulis mengenai bauran pemasaran BMT NU Sejahtera Kantor Cabang Harjamukti.

1. Product (Produk),

Produk merupakan sesuatu yang ditawarkan kepada pasar, bisa berupa produk nyata (tangible) atau tidak nyata (intangible/jasa), sehingga dapat memuaskan keinginan atau kebutuhan pasar (Shinta, 2011; Tjiptono \& Diana, 2020). Strategi produk bisa berupa strategi produk baru dan strategi produk yang sudah ada (Putri, 2017). BMT NU Sejahtera 
Kc. Harjamukti memiliki berbagai macam produk yang ditawarkan, seperti Simpanan Berjangka, tabungan pendidikan, umroh, dll. Produk merupakan faktor yang mempengaruhi pertimbangan nasabah dalam memilih lembaga keuangan syariah ( $\mathrm{K}$ Yulianto dkk, 2010; Andespa, 2017).

Sebagian produk BMT NU Sejahtera Kc. Harjamukti sudah ada nasabah yang menggunakan, namun sebagian lagi, masih ada produk yang belum memiliki nasabah atau pengguna produk. BMT NU Sejahtera melakukan modifikasi produk agar lebih menarik minat nasabah, seperti Produk Simpanan Khusus. Produk ini sebetulnya mirip dengan simpanan berjangka, namun nasabah bisa mendapatkan bagi hasil atau keuntungan seperti kendaraan bermotor dan mobil. Hal tersebut bisa lebih menarik minat nasabah. Namun terdapat juga beberapa produk lain yang belum ada nasabahnya, sehingga produk tersebut pun perlu dikemas lebih menarik serta bersinergi dengan promosi, agar informasi mengenai produk tersebut dapat sampai kepada nasabah dan menarik minat nasabah untuk menggunakannya.

2. Price (harga)

Selama masa pandemi covid 19, terdapat peningkatan tunggakan nasabah yang melakukan pembiayaan. Pembiayaan bermasalah yang disebabkan oleh nasabah bisa diakibatkan oleh dua hal, yaitu adanya unsur kesengajaan dan adanya unsur ketidaksengajaan. Namun selama masa pandemi covid 19 ini, pembiayaan bermasalah lebih dikarenakan unsur ketidaksengajaan, ketidaksetabilaan usaha yang berimbas pada penurunan pendapatan, menyebabkan terjadinya pembiayaan bermasalah. Menurut Tjiptono dan Diana, price atau harga, bisa berupa list price, diskon, jangka pembayaran dan syarat kredit (2020). Harga merupakan salah satu faktor yang mempengaruhi nasabah dalam menggunakan produk di lembaga keuangan syariah (Andespa, 2017).

BMT NU Sejahtera Kc. Harjamukti melakukan penyesuaian-penyesuaian dalam menangani pembiayaan bermasalah tersebut, seperti melakukan rescheduling (penjadwalan kembali) dan reconditioning (persyaratan kembali). Pertama yang dilakukan bisa berupa rescheduling, BMT NU Sejahtera Kc. Harjamukti memperpanjang jangka waktu pembiayaan atau jangka waktu angsuran. Nasabah diberikan keringanan berupa perpanjangan jangka waktu pembayaran. Misalnya perpanjangan waktu pembiayaan yang semula enam bulan, menjadi satu tahun. Hal tersebut diharapkan dapat membantu meringankan beban nasabah, karena waktu pengembaliannya lebih panjang. Kedua, yaitu BMT NU Sejahtera Kc. Harjamukti melakukan reconditioning (persyaratan kembali), yang dimaksud dengan reconditioning seperti penundaan pembayaran margin sampai waktu 
tertentu, tetapi pokok pinjaman tetap dibayar seperti biasa, atau bisa pula berbentuk penurunan besaran margin, sehingga bisa meringankan beban nasabah. Pengoptimalan dalam sisi price yaitu memberikan transparansi terhadap margin dan pinalti yang diberikan jika suatu saat nasabah ingin menarik dananya serta uang akan dikembalikan penuh pada jatuh tempo perjanjian yang telah disepakati, sehingga memberikan keyakinan penuh akan keamanan dalam menanamkan dana di dalam produk simpanan berjangka (SIMKA).

3. Place (lokasi)

Place, meliputi logistik perusahaan dan aktivitas pemasaran berkenaan dengan penyediaan dan pendistribusian produk akhir kepada konsumen (Tjiptono \& Diana, 2020). BMT NU Sejahtera Kc. Harjamukti berlokasi di Komplek Pusat Perdagangan Harjamukti, ruko 1 A No. 27 Cirebon. Lokasinya sangat strategis karena berada di pusat perdagangan, dan berada di ruko yang paling depan. Masyarakat bisa menggunakan jasa transportasi pribadi dan umum. Transportasi umum yang bisa diakses untuk bisa sampai ke pusat berupa angkutan umum, elf, bus maupun ojek online, Masyarakat banyak yang berdatangan ke pusat perdagangan Harjamukti, untuk berbelanja kebutuhan sehari-hari seperti sembako dan kebutuhan lainnya.

Hal tersebut menjadi peluang untuk BMT NU Sejahtera Kc. Harjamukti dalam memperoleh nasabah, baik dari masyarakat yang menjadi pengunjung pusat perdagangan, maupun para pedagang yang berjualan di pusat perdagangan Harjamukti. Hal tersebut sesuai dengan tujuan BMT NU Sejahtera yaitu, mengembangkan ekonomi umat dalam bentuk usaha mikro, kecil dan menengah dengan berpegang pada prinsip syariah. Lokasi merupakan faktor yang mempengaruhi pertimbangan nasabah dalam memilih lembaga keuangan syariah (K Yulianto dkk, 2010; Andespa, 2017).

Pada masa pandemi ini, BMT NU Sejahtera Kc. Harjamukti melakukan inovasi berupa penerapan protokol kesehatan di lokasi BMT NU Sejahtera Kc. Harjamukti. BMT menyediakan hand sanitizer di meja teller serta seluruh karyawan menggunakan masker. Hal tersebut merupakan upaya BMT NU Sejahtera Kc Harjamukti dalam melindungi kesehatan baik untuk pihak BMT dan para nasabah. BMT NU Sejahtera Kc Harjamukti perlu mengoptimalkan penerapan protokol kesehatan, seperti melakukan pengukuran suhu tubuh kepada nasabah yang datang ke lokasi BMT, serta memberikan penanda pada tempat duduk untuk mengatur jarak antar nasabah yang datang.

4. Promotion (promosi)

KSPPS (BMT) NU Sejahtera Kc. Harjamukti dalam menghadapi pandemi covid 19, tetap konsiten untuk melakukan promosi. Promosi merupakan aktivitas menyebarkan informasi, 
mempengaruhi/mengajak dana atau mengingatkan pasar sasaran mengenai perusahaan atau produknya agar bersedia menerima, kemudian membeli dan loyal pada produk ataupun jasa yang ditawarkan oleh perusahaan (Shinta, 2011). Promosi merupakan salah satu faktor yang mempengaruhi minat nasabah dalam menggunakan produk di lembaga keuangan syariah (Andespa,2017) dan mempengaruhi kepercayaan serta komitmen nasabah (Halik, 2016). Promosi yang bisa berupa periklanan, personal selling, promosi penjualan, public relation dan direct marketing.

Promosi yang dilakukan pihak KSPPS (BMT) NU Sejahtera Harjamukti antara lain melakukan periklanan melalui pembuatan brosur yang memuat informasi mengenai BMT serta produk-produk yang ditawarkan. Promosi selanjutnya yang dilakukan yaitu personal selling, BMT NU Sejahtera Kc. Harjamukti melakukan door to door (pintu ke pintu) dengan cara marketing datang langsung ke lokasi seperti, di pasar-pasar, kawasan pertokoan maupun rumah-rumah warga dimana produk-produk itu akan ditawarkan. Selain itu, BMT NU juga perlu untuk melakukan perluasan pemasran dengan cara kegiatan promosi yang intensif dan efisien (bakhri, 2019) yakni melalui online promotion, dengan memanfaatkan media sosial maupun web, agar penyebaran informasi mengenai profil dan produk-produk lebih luas. Selain itu, BMT NU Sejahtera perlu mengoptimalkan papan nama BMT yang terletak dipinggir jalan, namun tertutupi oleh pohon rindang dan beberapa barisan pedagang. Sehingga diperlukan perubahan, seperti dengan mempertinggi tiang papan nama, atau memindahkan ke lokasi yang mudah dilihat oleh masyarakat luas.

\section{KESIMPULAN DAN SARAN}

Koperasi Simpan Pinjam Pembiayaan Syariah (KSPPS) BMT NU Sejahtera cabang Harjamukti, mengalami perkembangan cukup pesat. Walaupun KSPPS (BMT) NU Sejahtera cabang harjamukti itu sendiri baru berdiri satu setengah tahun tetapi memiliki perkembangan yang cukup bagus. Pada bulan Maret 2020 wabah virus Covid-19 telah masuk ke Indonesia yang mengakibatkan terjadi masalah krisis ekonomi yang dampaknya dapat dirasakan oleh semua kalangan termasuk KSPPS (BMT) NU Sejahtera cabang Harjamukti.

BMT NU Sejahtera Kc. Harjamukti menghadapi tantangan berupa bertambahnya jumlah nasabah yang mengalami kesulitan dalam membayar pembiayaan, serta beberapa produk belum ada penggunanya. Analisis yang dilakukan yaitu dengan menggunakan bauran pemasaran berupa 4P, yaitu product (memodifikasi produk agar lebih menarik nasabah), price (penyesuaian produk pembiayaan agar lebih terjangkau oleh nasabah), place (menerapkan protokol kesehatan pada 
lokasi BMT Nu Sejahtera Kc. Harjamukti) dan promotion (tetap melakukan promosi berupa periklanan dan personal selling).

Berdasarkan hasil analisis dan pembahasan yang dilakukan, beberapa saran untuk BMT NU Sejahtera Kc. Harjamukti, yaitu:

1. Product: mengemas produk yang belum ada nasabahnya agar lebih menarik minat nasabah.

2. Price: memberikan transparansi margin dan pinalti

3. Place, meningkatkan protokol kesehatan di lokasi BMT, merubah papan nama BMT (mempertinggi atau menggeser) ke tempat yang strategis, agar lebih terlihat

4. Promotion: meningkatkan lagi promosi produk-produk yang ada di BMT melalui online promotion seperti website maupun media sosial

\section{UCAPAN TERIMA KASIH}

Terimakasih kami ucapkan kepada pihak BMT NU Sejahtera Kantor Cabang Harjamukti, yang telah berkontribusi mengizinkan sekaligus memberikan informasi yang dibutuhkan penulis dalam menyelesaikan kegiatan pendampingan ini.

\section{DAFTAR PUSTAKA}

Alma, Buchari. (2013). Kewirausahaan Untuk Mahasiswa Dan Umum. Bandung: Alfabeta.

Andespa, Rono. (2017). Faktor-faktor yang Mempengaruhi Minat Nasabah dalam Menabung di Bank Syariah. Al-Masraf: Jurnal Lembaga Keuangan dan Perbankan Al-Masraf. 2(1).

Astuti, Diah Meirani \& Sunanto, Sandra. (2016). Analisis Bauran Pemasaran Perbankan Terhadap Keputusan Pembelian Produk Taplus Bisnis PT Bank Negara Indonesia (Persero) TBK Cabang Perguruan Tinggi Bandung. Prosiding Seminar Nasional Manajemen Teknologi XXIV.

Bakhri, Syaeful., dkk. (2019). Analisis SWOT Untuk Strategi Pengembangan Home Industry Kue Gapit Sampurna Jaya Kabupaten Cirebon. DIMASEJATI: Jurnal Pengabdian Kepada Masyarakat. 1(1), 64-80.

Halik, Abdul. (2016). Pengaruh Bauran Pemasaran Jasa, Kualitas Layanan dan Nilai Religiusitas terhadap Kepercayaan Nasabah dan Implikasinya pada Komitmen Nasabah Bank Umum Syariah di Wilayah Gerbang Kertasusila Jawa Timur. JPH17: Jurnal Hasil Penelitian LPPM Untag Surabaya. 1(1).

K, Yulianto Firman, dkk. (2010). Analisis Pengaruh Faktor Bauran Pemasaran terhadap Pertimbangan Nasabah dalam Memilih Bank Syariah di Kota Medan. Wacana. 13(4).

Putri, BRT. (2017). Manajemen Pemasaran. Denpasar: Universitas Udayana. 
Rachma, Fikri Nur. (2018). Analisis Kepuasan Anggota Di KSPPS BMT NU Sejahtera KC Bawen. Fakultas Ekonomi Dan Bisnis Islam Institut Agama Islam Negeri Salatiga.

Ridwan, Muhammad. (2004). Manajemen Baitul Maal Wa Tanwil (BMT). Yogyakarta: UII Press

Shinta, Agustina. (2011). Manajemen Pemasaran. Malang: Universitas Brawijaya Press.

Tjiptono, Fandy \& Diana, Anastasia. (2020). Pemasaran. Yogyakarta: Andi.

Zuhria, S. E, \& Anwar, M. K. (2018). Pengaruh Bauran Pemasaran Bank Terhadap Loyalitas Nasabah (BTN Syariah KC Surabaya). Jurnal Ekonomi Islam, 1(1), 87-99. 